Original Article

\title{
First record of Trichodina heterodentata (Ciliophora: Trichodinidae) in banded knifefish Gymnotus carapo (Gymnotidae) cultured in Brazil
}

\author{
Primeiro registro de Trichodina heterodentata (Ciliophora: Trichodinidae) em tuvira \\ Gymnotus carapo (Gymnotidae), cultivado no Brasil
}

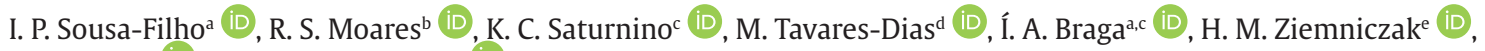 \\ C. N. Souto ${ }^{a}$ and D. G. S. Ramos ${ }^{* *}$ (iD \\ a Centro Universitário de Mineiros, Unidade Básica de Biociências, Mineiros, GO, Brasil \\ 'Universidade Federal de Jataí - UFJ, Unidade Acadêmica de Ciências Agrárias, Jataí, GO, Brasil \\ c Universidade Federal de Jataí - UFJ, Programa de Pós-graduação em Biociência Animal, Unidade Acadêmica Especial de Ciências Agrárias, Jataí, GO, Brasil \\ dEmpresa Brasileira de Pesquisa Agropecuária Amapá - Embrapa Amapá, Macapá, AP, Brasil \\ e Universidade Federal da Grande Dourados - UFGD, Faculdade de Ciências Agrárias, Dourados, MS, Brasil
}

\begin{abstract}
The aim of this study was to report the first record of Trichodina heterodentata in banded knifefish Gymnotus carapo. Banded knifefish cultivated in the municipality of Jataí, state of Goiás, in the central western region of Brazil, experienced fish mortality rates of 3-4\% per tank. Macroscopic analysis found that fish had lesions on their skin and gills. Smears of the integument and gills were confectioned and air-dried at room temperature and impregnated with silver nitrate to identify the Trichodinidae species causing the lesions. The trichodinid were identified as T. heterodentata, and their characteristics were compared to those from $T$. heterodentata recorded from other species of host fish. It was observed that the presence of $T$. heterodentata was associated with inadequate fish management, low water quality, high rates of stocking density, and inadequate nutritional management.
\end{abstract}

Keywords: fish farm, infestation, parasites, production, trichodinids.

\begin{abstract}
Resumo
O objetivo deste estudo foi relatar o primeiro registro de Trichodina heterodentata em tuviras Gymnotus carapo. Um cultivo de tuviras no município de Jataí, estado de Goiás, na região Centro-Oeste do Brasil, apresentou taxas de mortalidade de peixes de 3-4\% por tanque. A análise macroscópica constatou que os peixes tinham lesões na pele e brânquias. Raspados do tegumento e brânquias foram confeccionadas e secas ao ar à temperatura ambiente e impregnadas com nitrato de prata para identificar as espécies de Trichodinidae causadoras das lesões. Os tricodinídeos foram identificados como $T$. heterodentata, e suas características foram comparadas com as de $T$. heterodentata registradas para outras espécies de peixes hospedeiros. Observou-se que a presença de $T$. heterodentata estava associada ao manejo inadequado dos peixes, baixa qualidade da água, altas taxas de densidade de estocagem e manejo nutricional inadequado.
\end{abstract}

Palavras-chave: piscicultura, infestação, parasito, produção, tricodinídeos.

\section{Introduction}

The banded knifefish Gymnotus carapo Linnaeus, 1758, is a species in the order Gymnotiformes and the family Gymnotidae. Banded knifefish have electrical organs that are mainly used for electrocommunication (Rotta, 2004). Banded knifefish are distributed in Central and South America, from south-eastern Mexico to Paraguay, including Trinidad and Tobago (Froese \& Pauly, 2019). In their natural habitat, banded knifefish live in places with aquatic plants with dense roots that retain organic matter, and feed on small organisms, such as insects and microcrustaceans (Rotta, 2004;
Resende et al., 2006; Froese \& Pauly, 2019). This fish species is farmed in several places, including in central Brazil, for its use as live bait for sport fishing in rivers, lagoons, and even in fish-pays (Rotta, 2004). Hence, the use of banded knifefish in sport fishing stimulates the cultivation of this species, and the development of enterprises for its production. However, there is no available information about the parasites that infect cultivated banded knifefish. The present study expands our knowledge on this topic by describing the first record of Trichodina heterodentata Duncan 1977 from this fish species. 


\section{Material and Methods}

Banded knifefish are cultivated in the municipality of Jataí, state of Goiás, Brazil, for the purpose of producing baits for commercial use in sport fishing. The fish included in this study were kept at a local fish farm, 17²52'27.6"S and $51^{\circ} 37^{\prime} 49.3$ "W, in $500 \mathrm{~L}$ water tanks at densities of 90-110 fish per tank. There was neither renewal nor circulation of water, and fish were fed once a day with commercial feed $(0.8 \mathrm{~mm})$ containing $45 \%$ crude protein. The reservoirs were cleaned every two days, by siphoning and removing organic matter from the bottom of the tanks, and replacing approximately $5 \%$ of the water. At the fish farm included in this study, 3-4 fish per tank died, and the dead fish had small dark skin lesions. Six fish were sent to the Veterinary Pathology and Parasitology Laboratory at the Federal University of Goiás, in Jataí, for parasitological analysis. Smears of body mucus and gills were analyzed under an optical microscope (Nikkon Eclipse E200, Japan) for the presence of Trichodinidae Claus, 1874. The smears were air dried at room temperature and impregnated with silver nitrate for visualization of the adhesive discs of trichodinids (Lom, 1958).

\section{Results}

Trichodinid were identified as $T$. heterodentata (Figure 1), and compared with literature descriptions for $T$. heterodentata collected from other species of host fish (Table 1). We compared the measurements of the specimens in this study to those reported in other studies, and found that their characteristics were similar to those of T. heterodentata described by Duncan (1977), Martins et al. (2010), Pádua et al. (2012), and Miranda et al. (2012).

\section{Discussion}

Trichodina heterodendata has been described since 1977 from a variety of freshwater fish (Jager \& Basson, 2019), mainly in cichlid species (Basson \& Van As, 2006). In Brazil, T. heterodentata have been reported from small-scaled pacu Piaractus mesopotamicus Holmberg, 1887 (Pádua et al., 2012), channel catfish Ictalurus punctatus Rafinesque, 1818 (Martins et al., 2010), Nile tilapia Oreochromis niloticus Linnaeus, 1758 (Valladão et al., 2016), and in a hybrid toad species, Rhinella pombali Baldissera, Caramaschi \& Haddad, 2004 (Dias et al., 2009; Fernandes et al., 2011). However, $T$. heterodentata has not been previously reported in banded knifefish until present moment.

Jager \& Basson (2019) questioned the validity of the species $T$. heterodentata, based on the variety of reported morphometric data. Also, these authors pointed

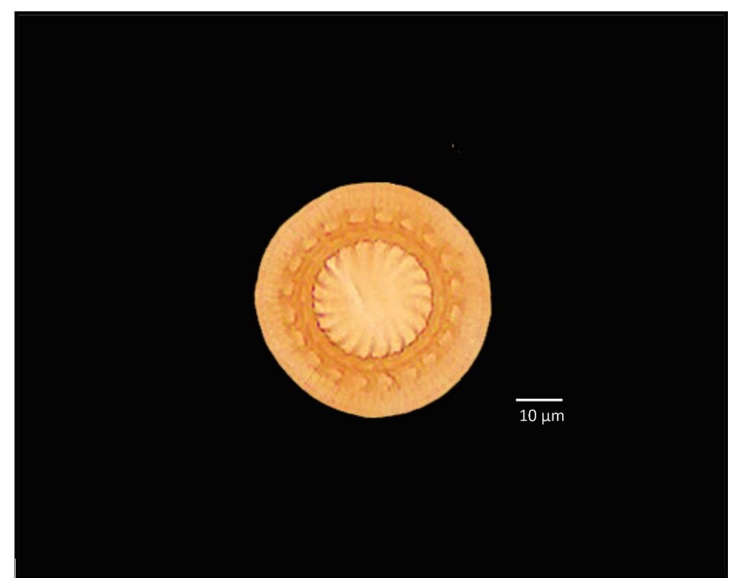

Figure 1. Trichodina heterodentata collected from the gills of banded knifefish, Gymnotus carapo, farmed in Jataí, state of Goiás, Brazil. Stain: silver nitrate impregnation.

Table 1. Measurements of Trichodina heterodentata collected from different species of host fish, including samples from Gymnotus carapo from Jataís, Goiás, Brazil.

\begin{tabular}{|c|c|c|c|c|c|}
\hline Fish species & $\begin{array}{l}\text { Banded knifefish } \\
\text { Gymnotus carapo }\end{array}$ & $\begin{array}{l}\text { Mozambique tilapia } \\
\text { Tilapia mossambica }\end{array}$ & $\begin{array}{l}\text { Channel catfish } \\
\text { Ictalurus punctatus }\end{array}$ & $\begin{array}{c}\text { Pirarucu Arapaima } \\
\text { gigas }\end{array}$ & $\begin{array}{l}\text { Small-scaled } \\
\text { pacu Piaractus } \\
\text { mesopotamicus }\end{array}$ \\
\hline Characteristic & Present study & Duncan (1977) & Martins et al. (2010) & Miranda et al. (2012) & Pádua et al. (2012) \\
\hline Body & $52.8 \pm 0.9(51.9-53.7)$ & $80(58.0-108.0)$ & $59.4 \pm 8.5(27.0-77.0)$ & $56 \pm 5.25(47.3-76.0)$ & $50.4 \pm 3.7(45.0-58.8)$ \\
\hline $\begin{array}{l}\text { Border } \\
\text { membranew }^{w}\end{array}$ & $4.3 \pm 0.2(4.1-4.5)$ & $4.7(3.4-5.5)$ & $5.1 \pm 1.7(3.0-7.0)$ & - & $4.3 \pm 0.4(3.5-5.5)$ \\
\hline Adhesive disc ${ }^{\mathrm{D}}$ & $45.0 \pm 3.8(41.2-48.8)$ & $57(45.0-74.0)$ & $60.2 \pm 6.7(40.0-72.0)$ & $45.7 \pm 3.8(37.1-51.3)$ & $41.2 \pm 3.3(35.1-49.7)$ \\
\hline $\begin{array}{l}\text { Denticular } \\
\text { ring }\end{array}$ & $30.8 \pm 0.2(30.6-31.0$ & $36(29.0-45.0)$ & $38.5 \pm 4.5(27.0-47.0)$ & $28.21 \pm 2.71(20-34.7)$ & $24.4 \pm 2.4(19.9-30.3)$ \\
\hline $\begin{array}{l}\text { Denticle } \\
\text { number }\end{array}$ & $20.0 \pm 0.0$ & $26(20.0-27.0)$ & $24.4 \pm 1.6(23.0-28.0)$ & $20.7 \pm 2.6(12-24)$ & $20(16.0-22.0)$ \\
\hline Denticle $^{\mathrm{L}}$ & $8.4 \pm 0.4(8.0-8.4)$ & $9.2(7.5-11.0)$ & $10.3 \pm 1.2(7.0-13.0)$ & $7.55 \pm 0.62(6.31-8.6)$ & $7.7 \pm 0.7(6.1-9.1)$ \\
\hline Blade $^{\mathrm{L}}$ & $3.5 \pm 0.2(3.3-3.7)$ & $5.7(4.7-7.1)$ & $6.2 \pm 0.8(4.0-8.0)$ & $4.46 \pm 0.59(3.9-5.5)$ & $4.6 \pm 0.4(3.7-5.5)$ \\
\hline Central part ${ }^{\mathrm{w}}$ & $2.0 \pm 0.0$ & $2.6(1.4-3.4)$ & $3.8 \pm 0.7(2.0-6.0)$ & $2.35 \pm 0.28(1.5-3.1)$ & $1.9 \pm 0.4(1.2-2.7)$ \\
\hline Denticle span & $14.1 \pm 0.3(13.8-14.4)$ & - & $18.4 \pm 2.2(12.0-22.0)$ & $3.19 \pm 1.74(7.1-15.7)$ & $13.7 \pm 0.9(11.6-15.5)$ \\
\hline
\end{tabular}

Means are followed by standard deviations, and in parenthesis, the minimum and maximum values. D: Diameter (in $\mu \mathrm{m}$ ), W: Width, L: Length. 
morphometric descriptions which can bring synonyms, such as Trichodina hypsilepis. However, this does not occur only with $T$. heterodentata. In fact, several species, not only of parasites, present different morphometric data, especially when they are cosmopolitan. Likewise, species with same morphology, but different taxonomy are re-arranged in a single taxon. This is the scientific dynamic that occurs in studies of species description and distribution. Surely, this study will not end the discussion on trichodinids and T. heterodentata. This study only provides data, so that within the evolution of this scientific knowledge, it will possibly be rearranged as the techniques evolve, and when the analyzing of specimens from various parts of the world becomes possible.

There was an outbreak of $T$. heterodentata in the examined banded knifefish due to the low water quality in the tanks and the excess of organic matter, which were visible. Ciliated trichodinids (Mobilida) are among the main etiological agents of mortality in farmed fish. Trichodinids are of great importance in fish cultivation, especially when the environment favors their reproduction, in which case severe infestations can damage the gills and skin of the fish, making them susceptible to respiratory problems and secondary infections (Zanolo \& Yamamura, 2006; Valladão et al., 2016; Rodrigues et al., 2019). In addition, the banded knifefish included in this study were farmed at a high stocking density (90-110 fish/500 L tank), which was well above the recommended stocking density for this species (approximately 100 fish for every 1,000 L of water, Ishikawa et al., 2017). High stocking densities are stressful for fish, making them susceptible to ectoparasite infections, including trichodinid infections.

In summary, the occurrence of $T$. heterodentata in banded knifefish was associated with poor fish management conditions, indicating the need for adequate management and sanitary conditions.

\section{Acknowledgements}

Dr. Marcos Tavares-Dias was supported by a research fellowship from the National Council for Technological Research and Development (Conselho Nacional de Pesquisa e Desenvolvimento Tecnológico (CNPq) Brazil) (Grant 303013/2015-0).

\section{References}

BASSON, L. and VAN AS, J.G., 2006. Trichodinidae and other ciliophorans (Phylum Ciliophora). In: P.T.K. WOO. Fish diseases and disorders. Oxfordshire: $\mathrm{CAB}$ International, vol. 1: Protozoan and Metazoan Infections, pp. 154-182.

DIAS, R.J., FERNANDES, N.M., SARTINI, B., DA SILVA-NETO, I.D. and D'AGOSTO, M., 2009. Occurrence of Trichodina heterodentata (Ciliophora: Trichodinidae) infesting tadpoles of Rhinella pombali (Anura: Bufonidae) in the Neotropical area. Parasitology International, vol. 58, no. 4, pp. 471-474. http://dx.doi. org/10.1016/j.parint.2009.06.009. PMid:19580885.

DUNCAN, B.L., 1977. Urceolariid ciliates, including three new species, from cultured Philippines fishes. Transactions of the American Microscopical Society, vol. 96, no. 1, pp. 76-81. http:// dx.doi.org/10.2307/3225966. PMid:403647.
FERNANDES, N.M., SARTINI, B., DIAS, R.J.P. and D'AGOSTO, M., 2011. Quantitative study of Trichodina heterodentata (Ciliophora: Mobilia) infrapopulations infesting tadpoles of a Brazilian endemic toad Rhinella pombali (Anura: Bufonidae). Zoologia, vol. 28, no. 6, pp. 777-783. http://dx.doi.org/10.1590/S198446702011000600011.

FROESE, R. and PAULY, D., 2019 [viewed 4 December 2019]. FishBase [online]. Available from: www.fishbase.org

ISHIKAWA, M.M., FERRI, G.H., DIAS, D.V.L., DONETTI, L.A.R. and QUEIROZ, J.F., 2017. Boas práticas de manejo para melhoria do treinamento alimentar de tuviras Gymnotus sp. Jaguariúna: Embrapa, 15 p. Circular Técnica, no. 27.

JAGER, G.P. and BASSON, L., 2019. Taxonomic assessment of three North American Trichodinids by reevaluating the taxon validity of Trichodina heterodentata Duncan, 1977 (Peritrichia). Acta Protozoologica, vol. 58, no. 3, pp. 125-139. http://dx.doi.org/1 0.4467/16890027AP.19.013.11914.

LOM, J., 1958. A contribution to the systematics and morphology of endoparasitic trichodinids from amphibians, with a proposal of uniform specific characteristics. The Journal of Protozoology, vol. 5, no. 4, pp. 251-263. http://dx.doi.org/10.1111/j.1550-7408.1958. tb02563.x.

MARTINS, M.L., MARCHIORI, N., NUNES, G. and RODRIGUES, M.P., 2010. First record of Trichodina heterodentata (Ciliophora: Trichodinidae) from channel catfish, Ictalurus punctatus cultivated in Brazil. Brazilian Journal of Biology $=$ Revista Brasileira de Biologia, vol. 70, no. 3, pp. 637-644. http://dx.doi.org/10.1590/ S1519-69842010000300022. PMid:20730352.

MIRANDA, L.H., MARCHIORI, N., ALFARO, C.R. and MARTINS, M.L., 2012. First record of Trichodina heterodentata (Ciliophora: Trichodinidae) from Arapaima gigas cultivated in Peru. Acta Amazonica, vol. 42, no. 3, pp. 433-438. http://dx.doi.org/10.1590/ S0044-59672012000300016.

PÁDUA, S.B., MARTINS, M.L., CARRASCHI, S.P., CRUZ, C. and ISHIKAWA, M.M., 2012. Trichodina heterodentata (Ciliophora: Trichodinidae): a new parasite for Piaractus mesopotamicus (Pisces: Characidae).Zootaxa, vol. 3422, no. 1, pp. 62-68. http:// dx.doi.org/10.11646/zootaxa.3422.1.4.

RESENDE, E.K., PEREIRA, R.A.C., SÓRIO, V.F. and GALVÃO, E.M., 2006. Biologia da tuvira, Gymnotus cf. Carapo (Pisces, Gymnotidae) no baixo Rio Negro, Pantanal, Mato Grosso do Sul, Brasil. Corumbá: Embrapa Pantanal, 42 p.

RODRIGUES, F.S., ASSANE, I.M., VALLADÃO, G.M.R., PAULA, F.G., ANDRADE, C.L., MORAES, A.P., DALL'AGNOL, M. and PASCOAL, L.M., 2019. First report of Trichodinella and new geographical records of trichodinids in Nile tilapia (Oreochromis niloticus) farmed in Brazil. Revista Brasileira de Parasitologia Veterinária, vol. 28, no. 2, pp. 229-237. http://dx.doi.org/10.1590/s198429612019038. PMid:31271640.

ROTTA, M.A., 2004. Aspectos biológicos e reprodutivos para a criação da Tuvira (Gymnotus sp.) em Cativeiro - I. Corumbá: Embrapa Pantanal, $30 \mathrm{p}$.

VALLADÃO, G.M.R., ALVES, L.O. and PILARSKI, F., 2016. Trichodiniasis in Nile tilapia hatcheries: Diagnosis, parasite: host-stage relationship and treatment. Aquaculture (Amsterdam, Netherlands), vol. 451, pp. 444-450. http://dx.doi.org/10.1016/j. aquaculture.2015.09.030.

ZANOLO, R. and YAMAMURA, M.H., 2006. Parasitas em tilápiasdo-nilo criadas em sistema de tanques-rede. Semina: Ciências Agrárias, vol. 27, no. 2, pp. 281-288. http://dx.doi. org/10.5433/1679-0359.2006v27n2p281. 